\title{
Is Technical Efficiency Affected by Farmers' Preference for Mitigation and Adaptation Actions against Climate Change? A Case Study in Northwest Mexico
}

\author{
Miguel Angel Orduño Torres ${ }^{1, * \mathbb{D}}$, Zein Kallas ${ }^{1, * \mathbb{D}}$, Selene Ivette Ornelas Herrera ${ }^{1} \mathbb{D}$ and \\ Bouali Guesmi ${ }^{2,3}$ \\ 1 Institute for Research in Sustainability Science and Technology (IS-UPC), Polytechnic University \\ of Catalonia, 08034 Barcelona, Spain; selene.ivette.ornelas@upc.edu \\ 2 Center for Research in Agrofood Economy and Development (CREDA-UPC-IRTA), Polytechnic University \\ of Catalonia, Institute of Agrifood Research and Technology, 08860 Castelldefels, Spain; \\ bouali.guesmi@upc.edu \\ 3 University of Carthage, Mograne Higher School of Agriculture, LR03AGR02 SPADD, Zaghouan 1121, Tunisie \\ * Correspondence: miguel.angel.orduno@upc.edu (M.A.O.T.); zein.kallas@upc.edu (Z.K.)
}

Received: 25 April 2019; Accepted: 10 June 2019; Published: 14 June 2019

check for updates

\begin{abstract}
Climate change has adverse effects on agriculture, decreasing crop quality and productivity. This makes it necessary to implement adaptation and mitigation strategies that contribute to the maintenance of technical efficiency (TE). This study analyzed the relationship of TE with farmers' mitigation and adaptation action preferences, their risk and environmental attitudes, and their perception of climate change. Through the stochastic frontier method, TE levels were estimated for 370 farmers in Northwest Mexico. The results showed the average efficiency levels (57\%) for three identified groups of farmers: High TE (15\% of farmers), average TE (72\%), and low TE (13\%). Our results showed a relationship between two of the preferred adaptation actions against climate change estimated using the analytical hierarchy process (AHP) method. The most efficient farmers preferred "change crops," while less efficient farmers preferred "invest in irrigation infrastructure." The anthropocentric environmental attitude inferred from the New Ecological Paradigm (NEP) scale was related to the level of TE. Efficient farmers were those with an anthropocentric environmental attitude, compared to less efficient farmers, who exhibited an ecocentric attitude. The climate change issues were more perceived by moderately efficient farmers. These findings set out a roadmap for policy-makers to face climate change at the regional level.
\end{abstract}

Keywords: technical efficiency; adaptation and mitigation preferences; climate change perception; environmental attitudes; farmers' risk attitude

\section{Introduction and Objectives}

For a growing number of researchers and policy-makers, the sustainable development of present and future societies, depends on paying immediate attention to the environmental problems related to climate change [1,2]. The uncertainty of changes generated by this phenomenon exposes the environment to high vulnerability [3]. Article 1 of the United Nations Framework Convention on Climate Change (UNFCCC) states that climate change is "attributed directly or indirectly to human activity that alters the composition of the global atmosphere and that adds to the natural variability of the climate observed during comparable periods of time" [4]. There are different strategies to address the adverse effects and impacts of climate change, and these can be realized by adopting two 
approaches: Adaptation and mitigation actions. Agriculture is one of the most sensitive sectors to climate change. Any variation in climate systems has a significant potential impact on productivity and on the processes related to farming activities [5]. Therefore, adaptation and mitigation actions can be implemented as differentiation strategies to reduce the risk of food insecurity [6] and production variability [7]. Adaptation is the ability to adjust to the impacts of climate change in the short term of natural or human systems [8]. Mitigation refers to actions aimed at reducing greenhouse gas emissions, with agriculture being an important source of the generation of these emissions [9].

Agriculture is of vital importance for the development of countries, especially developing nations, where the economy and family subsistence are based on food production and agricultural activities [10], given that in countries with lower incomes, $63 \%$ of the economically active population are employed in agriculture, while in developed countries only $3 \%$ are engaged in the agricultural sector [11]. Therefore, identifying the most preferred adaptation and mitigation actions turns out to be highly valuable. These preferences not only depend on farming activities, regions, and farmers' characteristics [12], but also could be related to technical efficiency (TE) at the farm level [13]. Agricultural TE implies obtaining the maximum production or output by using the minimum resources or input [14]. TE can be positively or negatively affected $[15,16]$ by farmers' decisions and preferences when adopting adaptation and mitigation actions. The agricultural TE level is related to the type of irrigation, sowing calendar, quality of seeds, water infrastructure, technology and machinery, quality of the land, and fertilizer use. It can also be related to farmers' risk and environmental attitudes, preferences for investment decisions, and socioeconomic characteristics, among other variables [16,17]. In this context, it is also assumed that TE at the farm level can be related to farmers' perception of climate change [18] and socioeconomic characteristics, among other variables.

The aim of this study is fourfold: First, to measure the level of technical efficiency using the parametric stochastic production frontier (SPF) method in order to identify its relationship to farmers' stated preferences for several climate change adaptation and mitigation actions, using the analytical hierarchy process (AHP). We seek to identify the direction and magnitude of the relationship between TE and farmers' preferences $[13,19]$. The second objective is to analyze the relationship between the level of TE and farmers' environmental attitude defined in two main dimensions, anthropocentric and ecocentric, using the New Ecological Paradigm (NEP) scale. The aim is to identify whether agricultural producers at a higher level of efficiency have an anthropocentric attitude [20]. The third objective is to establish whether there is a relationship between the level of TE and the stated risk attitude estimated using the multiple price list (MPL) method, also known as the lottery approach. The aim is to identify whether the most efficient farmers are risk-tolerant [21]. The fourth objective is to analyze the relationship between TE and the farmers' perception of climate change. The aim is to explore whether farmers who have a greater perception of the variation of climate change are more technically efficient [22].

The case study of the irrigation district DR076 belongs to the state of Sinaloa, the leading nationwide in grains, vegetables, and fruit production that supply several national and international markets. According to the FAO (2011), Sinaloa was considered the granary of Mexico, after its crops production accounted for $75 \%$ of the country's production. Given that in the study region there is no literature about TE at the farm level and its relationship with farmers' preferences when it comes to mitigation and adaptation actions, as well as with their environmental attitudes and risk behavior, this research aims to provide new knowledge that may help policy-makers to identify more effective strategies, involving stakeholders in creating agricultural and rural development policies.

Climate change is negatively affecting current agricultural systems, especially the rural areas in the developing countries due to their economic vulnerability and dependency on farming activities. The studied region shows similar features and characteristics with other agricultural regions in Mexico and agricultural systems worldwide. These similarities can be characterized in terms of the related adverse effects of climate change as well as farmers' characteristics and crops production systems. The results of this study provide evidence that support the idea that farmers' preferences for the 
adaptation and mitigation actions against climate change is related to their technical efficiency. These preferences' patterns can provide the decision makers with valuable information that allow them to identify effective policy measures replicable in other similar farming systems.

\section{Description of the Study Area}

Irrigation District DR076, Valle del Carrizo, is located in the state of Sinaloa, Mexico, bordered on the north by the state of Sonora, on the south by the Sierra Madre Occidental, and on the west by the Gulf of California. Its geographic location is at latitude $26^{\circ} 05^{\prime}$ north and longitude $108^{\circ} 53^{\prime}$ west, including part of the municipalities of Ahome and El Fuerte [23]. Its main economic activity is crop and livestock production; cereals such as wheat and corn are the most important crops, at $76 \%$ and $8 \%$ of total cultivated area, respectively [24]. The DR076 irrigation district is characterized by an extreme climate, in which atypical conditions have been highlighted in recent years, with high levels of precipitation in short periods of time as well as low temperatures [25]. This has repercussions on the technical efficiency of crop production and represents a threat to the food security of the region and the country [26].

\section{Materials and Methods}

\subsection{Survey Data}

This study reports on the findings of a survey carried out with 370 agricultural producers from DR076, whose sample size was determined based on the formula of finite populations, with a confidence level of $95 \%$ and a confidence interval of $4.99 \%$ [27]. The survey was designed with an interdisciplinary perspective, including economic, social, and demographic aspects. It included a wide set of questions grouped according to the farmers' socioeconomic characteristics, characteristics of their agricultural land and the types of crops [28], and their preference regarding the implementation of mitigation or adaptation actions related to reducing the effects of climate change using the AHP technique. Farmers' attitudes and opinions that define their behavior toward the environment were also determined using the NEP scale. Furthermore, their stated attitude about risk and perception of climate change-related impacts were identified (see Figure 1). The survey was administered by undergraduate students of the Intercultural Autonomous University of Sinaloa and was conducted from October to December 2017. The questionnaire was approved by the ethics committee of the Intercultural Autonomous University of Sinaloa and was conducted according to ethical principles in social science, with specific care taken to protect personal information according to national regulations. Before the survey was conducted, farmers signed a consent form and received an explanation of the questionnaire.

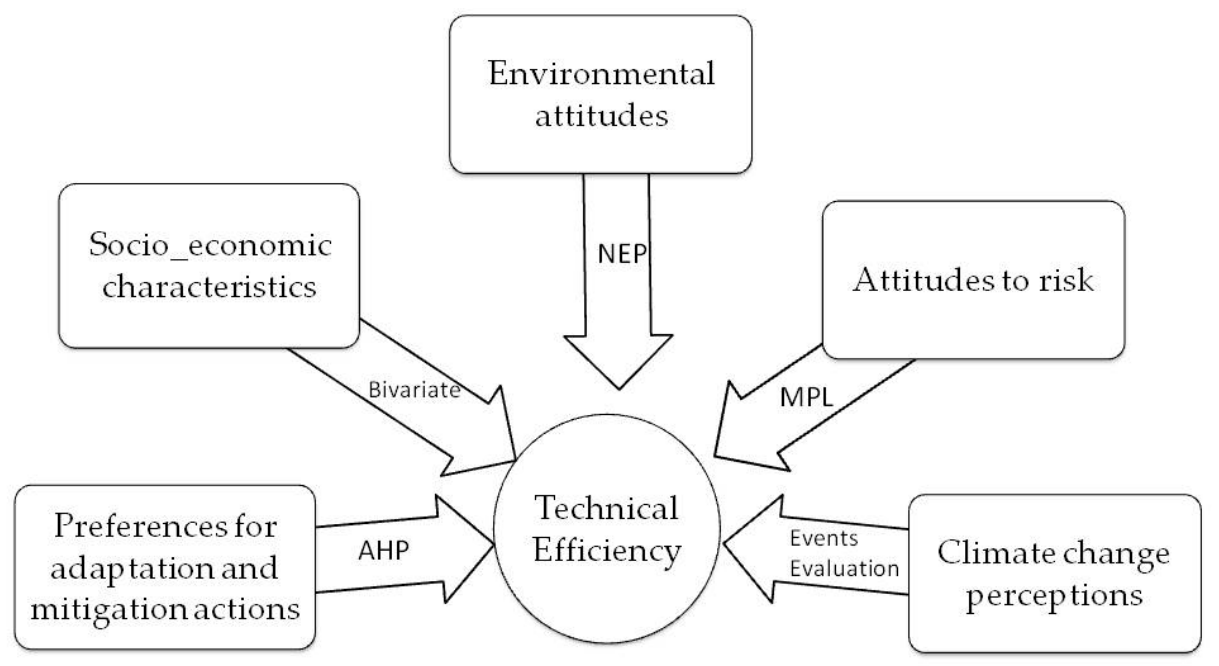

Figure 1. Methodological approach. 


\subsection{Technical Efficiency}

The parametric stochastic production frontier (SPF) was used to estimate the technical efficiency (TE) scores. This approach was simultaneously proposed by Aigner et al. (1977) and Meeusen and Van den Broeck (1977) $[29,30]$. The SPF model can be specified as

$$
Y_{i}=f\left(X_{i} ; \beta\right) \exp \left(e_{i}\right) ; e_{i}=v_{i}-u_{i}, i=1,2, \ldots, N
$$

The dependent variable $\left(Y_{i}\right)$ is expressed in currency units, Mexican pesos (Mex\$), and represents the total farm income. Among the inputs considered as explanatory variables is the total land devoted to crop production $\left(X_{1}\right)$, measured in hectares. Total labor inputs $\left(X_{2}\right)$ is composed of family and hired labor, representing the number of employees on the farm. $\left(X_{3}\right)$ defines expenditure on seeds, expressed in Mex\$. Chemical inputs $\left(X_{4}\right)$ aggregates the value of fertilizers and crop-protection products used in the production process. Farming overhead $\left(X_{5}\right)$ includes irrigation, energy, fuel, and other expenses and is also measured in monetary units.

Using these variables, TE scores were computed as an output-oriented measure and defined as the ratio of observed output to the corresponding SFP, with values in the range of zero to one [31]. According to the estimated TE values, farmers were grouped into three groups, taking account of the mean and one unit upward and downward standard deviation to establish farmers with low, medium, and high efficiency.

\subsection{Farmers' Preferences for Climate Change Mitigation and Adaptation Actions}

Taking a multicriteria approach to decision-making problems, farmers' preferences for different climate change adaptation and mitigation actions were identified using the analytical hierarchy process (AHP). This technique is widely used in the resolution of problems of an agrarian and environmental nature [32]. The AHP was developed by Saaty in the 1970s [33]. This tool has a mathematical approach that breaks down any problem into parts or clusters and analyzes them in a hierarchical structure. It allows the assessment of quantitative and qualitative criteria using a common scale [34]. The hierarchical modeling carried out in AHP allows the conversion of subjective evaluations according to the relative importance between different attributes or criteria into a set of weights or global weights to facilitate decision-making.

According to the AHP, the criteria (in our case mitigation and adaptation actions) are compared using a pairwise approach, in which the researcher estimates the relative importance of each criterion in order to identify the best alternative as a solution to the problem proposed. By applying the AHP, it was possible to perform an analysis of each option in relation to the others through paired comparisons, facilitating an estimation of farmers' preferences.

The methodological structure of this tool is given by three stages: Modeling, evaluation, and prioritization. During the modeling stage, the problem is defined (i.e., identification of farmers' preferences for mitigation and adaptation actions). In this case, the appropriate criteria were identified from a literature review [12]. The identified criteria are shown in Table 1.

Table 1. Criteria of climate change impact reduction.

\begin{tabular}{ll}
\hline \multicolumn{1}{c}{ A Adaptation Measures [35] } & \multicolumn{1}{c}{ M Mitigation Measures [36] } \\
\hline A1 Invest in improved irrigation facilities [37] & M1 Use organic agriculture [38] \\
A2 Change crops [39] & M2 Use zero tillage management [40] \\
A3 Introduce improved and resistant seeds [41] & M3 Use renewable energy [42] \\
A4 Adapt the sowing calendar [43] & M4 Use low-polluting emission and energy-efficient machinery [44] \\
\hline
\end{tabular}

Accordingly, the decision model was structured in the form of a hierarchy, grouping the clusters into different levels (Figure 2), which were used to carry out the paired comparisons of the elements of each cluster based on the verbal scale. 


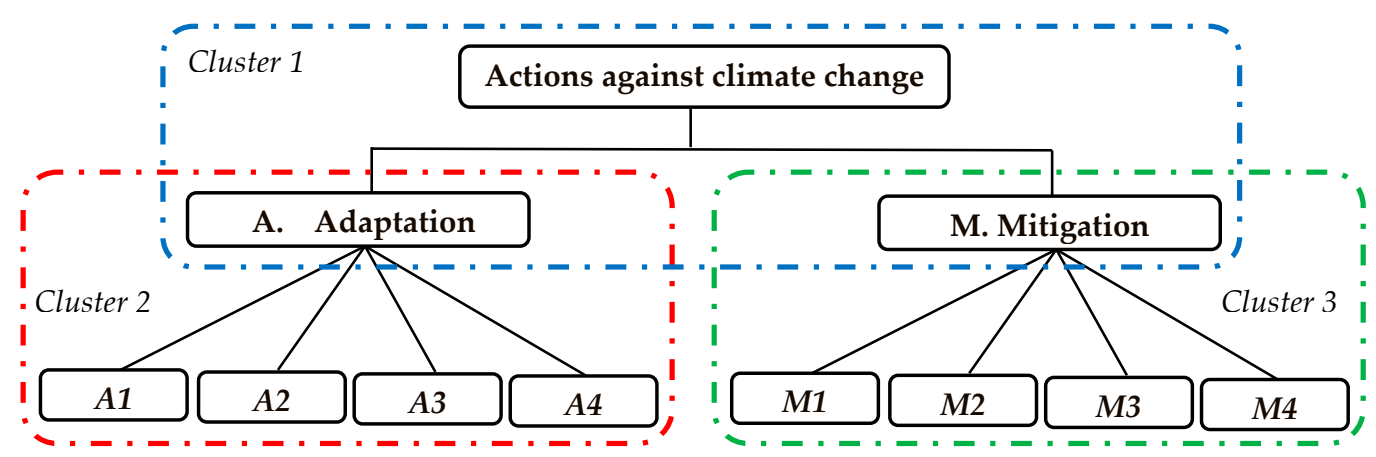

Figure 2. Identification of clusters that make up the decision hierarchy model [8].

The comparison structure has a pair of criteria (A and $\mathrm{M}$ ) and a scale in both directions from one to nine; this allows establishing which of the two criteria was preferred and a measure of the relative importance of the preferred criterion (see Table 2).

Table 2. Structure of comparison scale between criteria (cluster 1).

\begin{tabular}{|c|c|c|c|c|c|c|c|c|c|c|c|c|c|c|c|c|}
\hline \multicolumn{8}{|c|}{ A. Adaptation Measures. } & \multicolumn{9}{|c|}{ M. Mitigation Measures } \\
\hline 9 & 8 & 7 & 6 & 5 & 4 & 3 & 2 & 1 & 2 & 3 & 4 & 5 & 6 & 7 & 8 & 9 \\
\hline
\end{tabular}

Once the hierarchy is structured, the actions corresponding to the assessment stage are carried out. This stage corresponds to administering the questionnaire, when the interviewees are asked for the degree of importance they assign to their preference in each pair of criteria in each cluster, identified as mitigation or adaptation actions. (The complete experimental design of the paired comparisons question can be seen in the questionnaire, available in the Supplementary Materials, question 36.)

The third stage is prioritization and synthesis. At this stage, the farmers' expressed preferences in the paired comparisons $\hat{a}_{i k}$ are used to construct the Saaty matrix $\left(\hat{\mathrm{A}}_{k}\right)$ of each cluster, with dimensions $\mathrm{n} \times \mathrm{n}=4 \times 4$ (where $\mathrm{n}$ corresponds to the number of actions within the cluster) and the vector of eigenvalues with the normalized weights corresponding to the cluster in question, which serve to obtain the relative importance, also known as the priority or local weight $\hat{w}_{i k}$ of the attribute, according to the weighting of judgments issued by the individual $(k)$, which can be estimated by means of the row geometric mean method (RGMM), which will allow multifunctionality assessment to be carried out. The estimation of relative importance $\left(\hat{w}_{i k}\right)$ was carried out using the Super Decisions software [46]. The verification of farmers' consistency using the consistency ratio [47] showed an average value less than $10 \%$, which is acceptable according to the AHP literature [48]. Finally, in order to obtain the general results of the weight of each attribute, the process was repeated for each individual who was part of the sample $(k=1$ to 370$)$.

\subsection{Farmers' Environmental Attitudes and Opinions by NEP Scale Method}

Given current environmental concerns, the study of human attitudes and behaviors toward the environment has become increasingly relevant. These environmental attitudes or opinions can be approximated and expressed by positive or negative evaluations of the relationships between humans and the natural environment $[49,50]$. There are several methods and scales to approximate individuals' attitudes toward the environment. The Environmental Concerns alternative is a scale that pays specific attention to issues related to transportation, environmental pollution, biodiversity protection, and natural resource use, as well as consumption behavior [51]. The Proactive-Reactive Environmental Management scale is another alternative that allows the evaluation of different environmental practices, 
in which the proactive actions are aimed at modifying the processes that negatively affect the environment and the reactive ones are aimed at repairing current negative effects [52].

Among the array of alternative methods to measure environmental attitude, the New Ecological Paradigm (NEP) scale is one alternative that can be adapted to identify the psychological tendency reflecting the relationship that humans have with the environment $[53,54]$ in an economic context, such as agricultural production. Individuals' attitudes can be identified as latent environmental dimensions principally reflecting an ecocentric or anthropocentric perspective. An ecocentric attitude is related to statements in which someone expresses a vision in favor of nature, considering that humans cause disequilibrium by their use of the environment, while an anthropocentric attitude considers that the environment can support the intensive use of natural resources, expressed through statements in which humans are said to have supremacy [55]. In this study, we used an NEP scale composed of 16 statements in order to analyze farmers' environmental attitudes. The agreement level for each statement was measured according to a 9-point Likert-type scale, where one represents total disagreement with the statement, five corresponds to a neutral opinion, and nine represents total agreement with the statement. The statements used in the experimental design to identify farmers' latent environmental dimensions can be seen in the questionnaire, available in the Supplementary Materials, question 27.

\subsection{Farmers' Risk Attitude Using the MPL Lottery Method}

Decision-making under uncertainty depends to a large extent on the risk attitude of economic agents. It is related to each person's behavior and influenced by socioeconomic factors and experiences [56]. In the agricultural field, the decisions made by farmers are affected by their level of aversion to or tolerance of risk that is related to their farm management and crop cultivation strategy and periodicity. They are also related to farmers' attitudes toward the environment and their perception of climate change [12].

The multiple price list (MPL), also known as a "lottery," is one of the tools most recently used to identify farmers' stated attitudes about risk under uncertainty (i.e., the level of risk tolerance or aversion). It relates levels of risk with reward or loss in a lottery. According to this method, an array of eight questions is proposed as lottery scenarios, with a pair of hypothetical alternatives from which to select, option A and option B, both with constant probabilities in each scenario. Option A (the safe option) determines the level of risk aversion, and depending on the number of scenarios in which the interviewee selects this option, once he/she decides to change to option B (the risky option), the interview must be stopped to avoid inconsistencies. If a farmer selects the risky option (option B) in the first scenario, it indicates that he/she is tolerant of risk; if the farmer selects option A in the first three scenarios and it then changes to option B in scenario four, it indicates that he/she has a neutral attitude toward risk; and a risk-averse farmer will choose the safe option (option A) in all scenarios [57]. According to the Holt and Laury scale, a risk-tolerant person corresponds to a risk coefficient from -1.75 to less than -0.15 , a risk-neutral person corresponds to a risk coefficient from -0.15 to less than 0.14 , and a risk-averse person corresponds to a risk coefficient of 0.14 or greater [58]. The experimental design used to identify the declared level of risk can be seen in the Supplementary Materials, question 35.

\subsection{Farmers' Perceptions of Climate Change}

The perception of climate change in farming activities is based on an analysis of the variability of phenomena such as increased temperature; varied levels and timing of rainfall; decreased soil fertility; increased periods of drought; decreased yields; increased drought episodes, frosts, floods, hailstorms, and plagues; and changes in vegetation [59]. Farmers' perceptions of climate change are also relevant as they are related to their farming decisions and practice [60]. Statements related to these phenomena identified from the literature [61-69] were used to evaluate farmers' agreement or disagreement using a Likert-type scale ranging from one to nine, where one corresponds to absolute disagreement and nine 
corresponds to absolute agreement with the statement. The proposed statements allow an assessment of farmers' opinions on issues such as the instability of meteorological factors and events related to climatic conditions.

\section{Results and Discussion}

\subsection{Technical Efficiency}

Results show that the average TE estimate is 0.57 , indicating that farmers reach $57 \%$ of their maximum potential output, and the majority of them have average efficiency scores ( $72 \%$ moderately efficient, $13 \%$ low TE score, and $15 \%$ high TE score). Moreover, results suggest that farmers could increase their output by $43 \%$ on average if they used available resources more effectively with the same production technology. Thus, there is a large opportunity to improve TE by a more rational and less arbitrary use of inputs that would reduce production costs and contribute to the farm's livelihood.

It is considered that low efficiency may be associated with a misuse of existing technology, so optimization has to do with, among other things, optimizing the irrigation infrastructure, focused on substantially reducing water and energy consumption [70], given that, generally, energy consumption can be considered one of the most significant expenses associated with agricultural production. Additionally, reducing energy consumption would bring economic savings and reduce polluting emissions in the environment, resulting in a more sustainable form of agriculture.

Results also show that farmers who use family labor to a greater extent instead of hiring labor dedicated exclusively to agricultural activities have less technical efficiency, which indicates a need for greater professionalization and specialization of the people in charge of tasks in the field. This result differs from that obtained in a study [71], in which the presence of family labor greatly improved technical efficiency [72]. This difference could be attributed to the size of the farm, which in our case study was about 10.60 ha on average. When the size of the farm increases, more specialized labor is required and family labor may not be able to satisfy the need. In any case, it is important to note that Marquez et al. (2013) also indicate that the significance of this relationship can also be related to the methodological framework used to estimate TE.

Another action that we believe contributes to an improvement of technical efficiency is changing crops, given that the type of crop defines the amount of resources required, such as water, fertilizers, labor, machinery, etc. [73]. In addition, implementing more ecological techniques such as zero tillage contributes to increased technical efficiency due to a decreased use of energy resources and labor on the farm [74] (unlike conventional agriculture, which uses intensive tillage, significantly increasing costs for energy consumption, causing additional soil erosion, runoff, and pollution by sediment, with fertilizers and pesticides that will impact the subsoil and aquifers).

\subsection{Adaptation and Mitigation Preferences}

The results of the analysis of preferences estimated by the AHP method (Table 3) reveal that mitigation actions ( $\mathrm{M}=58.19 \%)$ were relatively more preferred compared to adaptation ones $(\mathrm{A}=41.81 \%)$. The highest in relative importance compared to other actions is the mitigation alternative "use low-polluting emission and energy-efficient machinery" (M4 = 17.94\%). These results, in relation to climate change impact reduction, show that mitigation actions must be a priority, as also affirmed by Bragado (2016) [75]. The second most popular option was the alternative "use zero tillage management" $(\mathrm{M} 2=14 \%)$, and the third was "use renewable energy" $(\mathrm{M} 3=13.71 \%)$. 
Table 3. Farmers' prioritization of different actions (relative relevance) faced by the impact of climate change on their activities.

\begin{tabular}{|c|c|c|c|c|c|}
\hline Criteria. & Local Weight & & Attributes & Local Weight & Global Weight \\
\hline & (Cluster 1) & & & (Cluster 2) & Cluster $1 \times$ Cluster 2 \\
\hline \multirow{6}{*}{ Adaptation } & \multirow{4}{*}{41.81} & A1 & Invest in improving irrigation facilities & $22.74 \%$ & $9.27 \%$ \\
\hline & & $\mathrm{A} 2$ & Change crops & $25.99 \%$ & $10.60 \%$ \\
\hline & & A3 & Introduce improved and resistant seeds & $28.03 \%$ & $11.43 \%$ \\
\hline & & A4 & Adapt sowing calendar & $23.25 \%$ & $9.48 \%$ \\
\hline & & & Local Total & $100.00 \%$ & - \\
\hline & \multirow{7}{*}{58.19} & & & (Cluster 3) & Cluster $1 \times$ Cluster 3 \\
\hline \multirow{6}{*}{ Mitigation } & & M1 & Use organic agriculture & $22.77 \%$ & $13.48 \%$ \\
\hline & & M2 & Use zero tillage management & $23.79 \%$ & $14.09 \%$ \\
\hline & & M3 & Use renewable energy & $23.15 \%$ & $13.71 \%$ \\
\hline & & M4 & $\begin{array}{l}\text { Use low-polluting emission and } \\
\text { energy-efficient machinery }\end{array}$ & $30.29 \%$ & $17.94 \%$ \\
\hline & & & Local Total & $100.00 \%$ & - \\
\hline & & & & Global total & $100.00 \%$ \\
\hline
\end{tabular}

According to the relative relevance assigned to adaptation and mitigation options (see Figure 3), we identified how many farmers in the sample assigned the highest global weight to each option. The action most preferred by farmers to reduce the effects of climate change was M4, "Use low-polluting emission and energy-efficient machinery," a mitigation action; the second and third preferred actions were A1, "Invest in improved irrigation infrastructure," and A2, "Change crops," both adaption options.

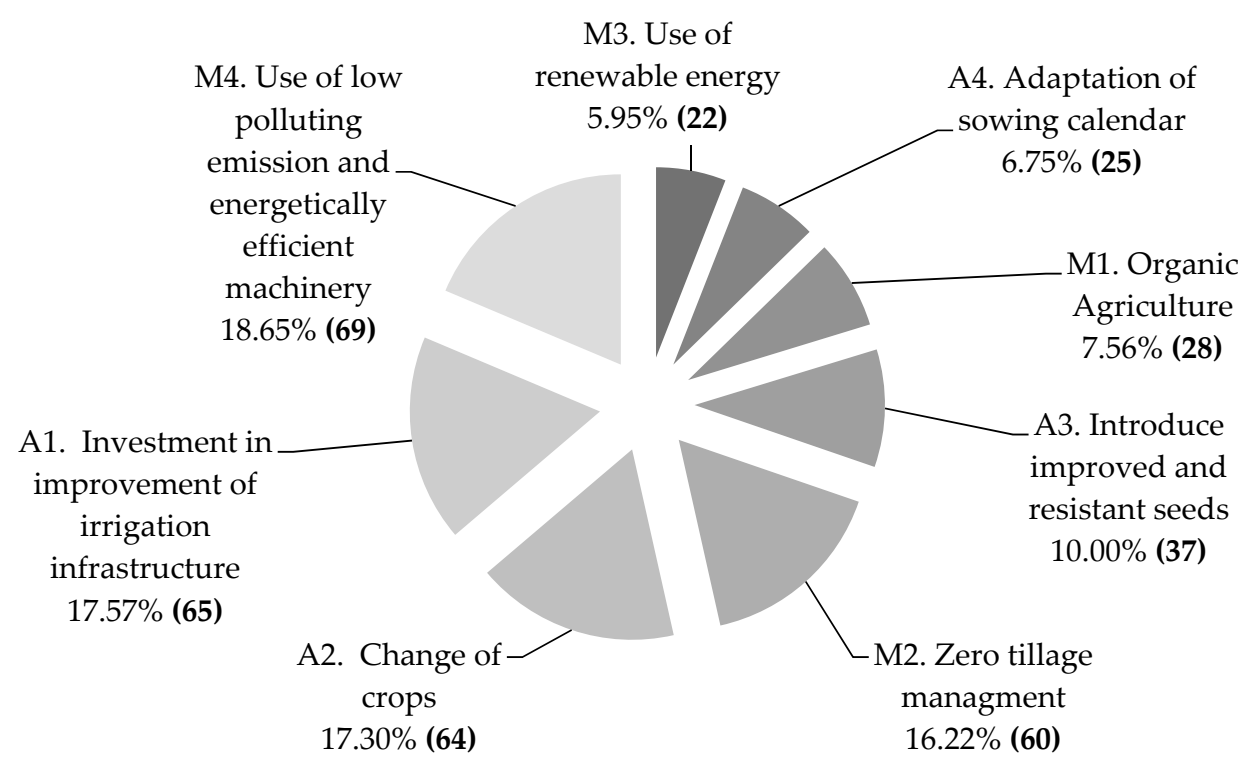

Figure 3. Distribution of farmers' preferences for climate change adaptation and mitigation actions.

\subsection{Environmental Attitudes}

According to the analysis of environmental attitudes, the NEP scale showed that two-thirds of farmers had a positive position on the environment, emphasizing their ecocentric attitude (see Figure 4), which means that most farmers consider nature to be a good thing that should be protected regardless of whether it generates direct benefits or not, such as through responsible consumption and use of clean energy. Furthermore, farmers expressed a higher preference for maintaining environmental resources and the regeneration of natural processes. The remaining farmers had an undefined position on the environment. They expressed agreement with affirmations where the importance of nature is highlighted and with affirmations that defend the human right to use environmental resources. However, in other cases, both affirmations received a high level of disagreement, showing an unclear relationship. There is no conclusive opinion on the environment, that is, they generally do not have a 
clear environmental opinion; they agree with some ecocentric attitudes and anthropocentric attitudes, or they absolutely disagree with both [76].

Distribution of farmer attitudes toward the environment

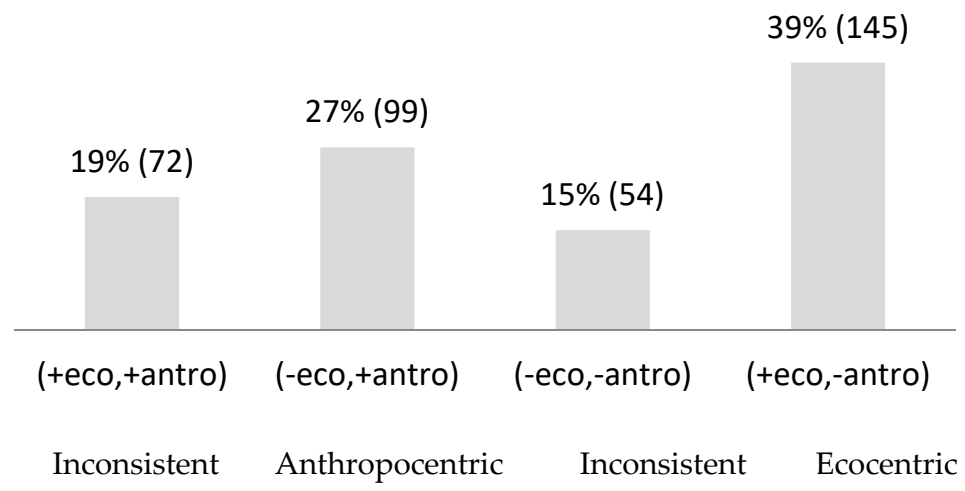

Figure 4. Farmers' environmental attitudes.

\subsection{Risk Attitudes}

Through the analysis of risk attitudes using the MPL method, it was observed that according to the scale proposed by Holt and Laury [58], approximately $51 \%$ of farmers had an attitude of risk aversion, while $41 \%$ were risk-tolerant and $8 \%$ had a neutral attitude about risk. The estimated average of the farmers' risk level had a value of 0.32 , placing the farmers studied as slightly averse to risk according to the scale. This result is consistent with results on the level of risk aversion obtained in other studies, such as Pennings and Garcia (2001) and Brick et al. (2012) [57,77].

\subsection{Climate Change Perceptions}

The results of the analysis of climate change perceptions show that farmers perceived a high degree of variation in all climate phenomena presented in the experimental design, according to the answers given during the interview using a 9-point Likert-type scale, where one is absolute disagreement and nine absolute agreement with the statement. Most important was the increasing incidence of diseases and pests (8.23), followed by increased weed problems (7.92), increased temperature (7.46), and the presence of frost episodes (5.98).

\subsection{Socio-Economic Characteristicus}

Finally, the TE efficiency was related to the socio-economic variables (age, education level, income and percentage of income coming from agricultural activities, origin of their agricultural training education, number of generations devoted to agriculture and property management regime). Results showed that age, property regime and the percentage of income coming from agriculture were significantly related to TE. Young farmers that are owner of their agricultural land with more than $50 \%$ of their income coming from agriculture activities are more technically efficient. These results are in line to the finding in Guesmi et al., (2010) and Perdomo and Mendieta (2007) highlighting the age and income variable as determinant factors of TE [31,78].

\subsection{Technical Efficiency with Regard to Farmers' Preferences, Risk, and Environmental Attitudes and Climate Change Perceptions}

As commented above, technical efficiency scores were related to farmers' preferences for adaptation and mitigation actions, environmental attitudes, risk attitude, and climate change perceptions. An analysis of heterogeneity was made by ANOVA and PCA to statistically contrast whether any of these results characterizing farmers' attitudes were related to their level of TE. 
Results showed two clearly independent dimensions (see Figure 5) that explain $52.28 \%$ of the total variance. In Figure 5, the horizontal axis represents climate change perception. Farmers on the right side are more sensitive and farmers on the left side are less sensitive to climate change problems. The vertical axis represents TE, environmental attitudes, and preferences for significant actions against climate change. Farmers on the upper part are more efficient compared to the lower part. The same description also holds for anthropocentric and ecocentric attitudes. Finally, the preference for crop changes is located on the opposed side of the preference for improving irrigation systems as adaptation actions.

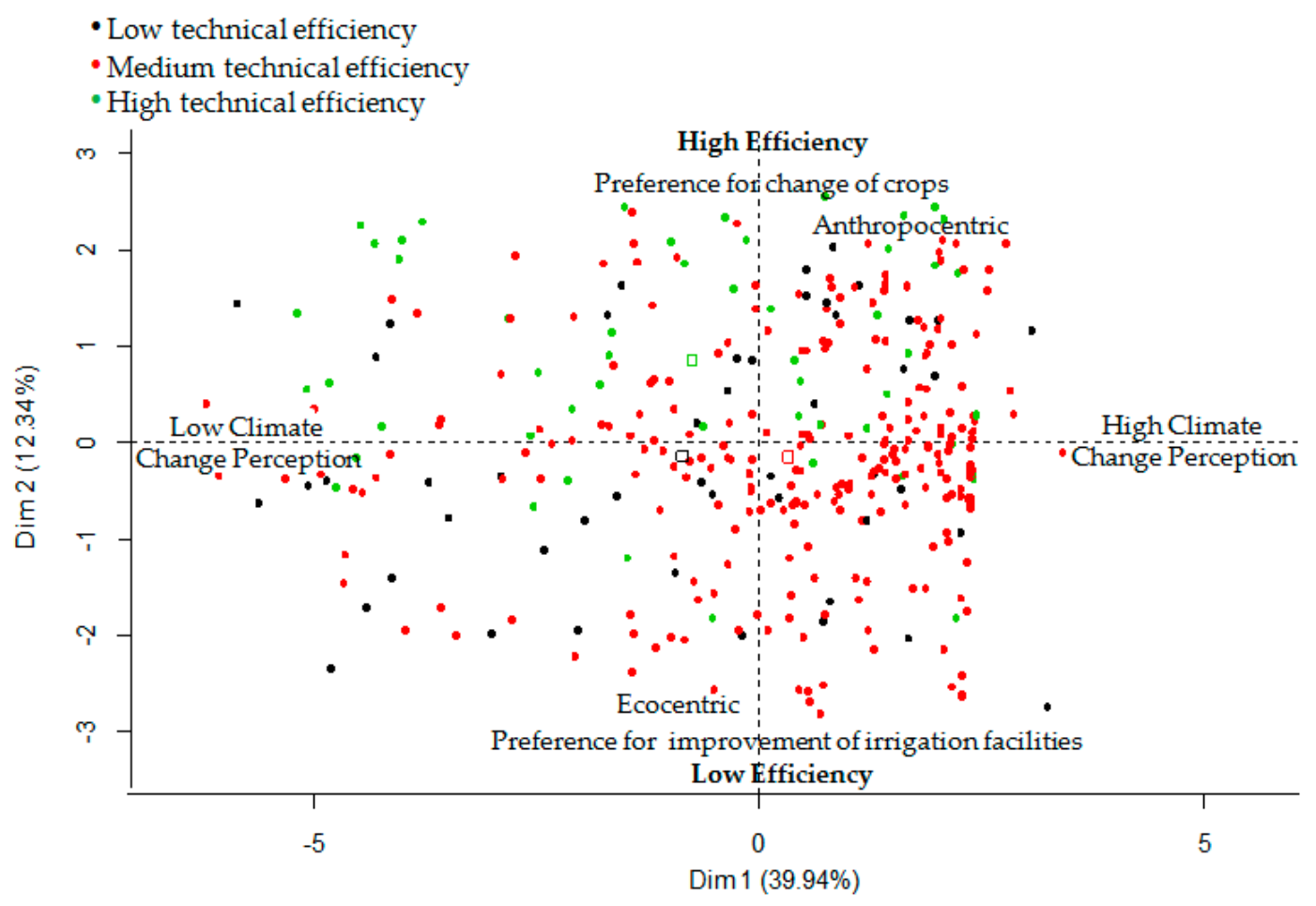

Figure 5. Technical efficiency as related to farmers' preferences, environmental attitudes, and climate change perception.

Results show that the most efficient farmers (green dots) preferred the "change crops" adaptation action, highlighting the importance of adopting new, productive, low-water-demand and disease-resistant varieties to face climate change. According to Estrada et al. (2006), crops must be diversified to maximize yields, yet generally farmers do not diversify but specialize in a specific crop, citing economic factors for this decision [79]. These farmers exhibited an anthropocentric attitude toward the environment, highlighting relatively less sensitivity to climate change issues. In particular, lower perception was found regarding the variation of environmental phenomena such as droughts and freezing episodes. Derived from previous results, as also commented by Ovares (2016), climate change perception is related to anthropocentric attitudes [80], and we can argue that a lack of environmental interest or ignorance of the effects of production activities on the environment is related to unawareness of climate variation. In this context, it is necessary to identify whether technical efficiency has been achieved to the detriment of the environment.

Farmers with lower technical efficiency (black dots), preferred the investment in irrigation facilities as an adaptation action and exhibited ecocentric attitude. This low level of TE could be related to their extensive production system and to the type of farming managements. These include the adoption of low soil degradation strategy by applying zero or low tillage agriculture, low use of phytosanitary and following a natural crop rotation. The less efficient farmers are taking advantage of the available natural resources with low adopting level of technological innovations. This result is similar to the finding 
of Alvarez and Del Corral (2010) who stated that farmers adopting intensive agriculture technology are more productive and more technically efficient than the extensive ones [81]. In this context, the decision-making of ecocentric farmers is driven not only by their economic objectives but also by the environmental one. They tend to preserve the environment as an input of their activities that ensure the generation of a satisfactory income [28]. The ecocentric farmers could adopt agricultural technologies that positively impact their productivity and are environmental friendly [82], such as the adoption of efficient irrigation system. From a sustainable agriculture point of view, a balance is required between their economic, social and environmental components. Otherwise, any other position in favour of only one of these factors it supposes the detriment of the rest.

Their perception of climate change was not clearly defined, with a slight tendency toward low perception levels. According to these results, we can deduce that the main problem faced by less efficient farmers is the availability of water, or specifically the need to optimize its use, given the high cost of water in the production of crops. Irrigation systems are a key element in achieving high technical efficiency in agricultural production [83]. The unclear position regarding climate change does not allow them to identify that the cost derived from water consumption is due to the increased use of water because of variation in the climate (greater evapotranspiration due to increased temperature, lower humidity in soil as a result of drought). The effects of climate change, identified by farmers mainly as increasing temperature and increased incidence of diseases and pests and weed problems, were perceived to a greater extent by moderately efficient farmers.

Finally, according to the results of this study, non significant evidence was found for a relationship between the stated attitude about risk and technical efficiency. This could be related to the nature of the data, with relatively homogeneous outcomes, with most producers in the region being risk averse and moderately efficient.

\section{Conclusions}

Rural areas that are vulnerable to the impacts of climate change, where agriculture plays a relevant economic role, show the importance of implementing region-specific adaptation and mitigation strategies to improve the level of technical efficiency at the farm level. Adopting these actions does not imply greater technification of the field, but better use of currently available resources and inputs by introducing alternative farm management systems such as using organic agriculture and zero tillage, adapting the sowing calendar, and changing crops.

The effects of climate change on agro systems depend on the type of agricultural production system implemented. Thus, it is necessary to adapt these systems according to the changing requirements of the natural environment caused by climatic variation, in order to increase production capacity through the optimal use of available resources, resulting in a higher level of technical efficiency.

Our results suggest a need to take advantage of available resources in order to face the adverse effects of climate change. Adopting the use of improved seeds and changing crops are among the most important actions according to farmers' preferences. Agricultural policy-makers must generate incentives for farmers in the region to adopt these types of adaptation actions, and disseminate technical information on best practices to encourage them to put these actions into practice.

In relation to farmers with less technical efficiency, whose environmental attitude was more ecocentric, their ecological efficiency should also be accounted for through more sustainable use of water resources, as this is one of the main factors that negatively affects agricultural performance.

In the agricultural sector, the economic policies that are implemented must be aimed at increasing the income and improving the livelihoods of rural households in order to improve their capacities and productive assets through the sustainable use of resources. Our results show that competent authorities need to include several actions that could represent a roadmap in the region studied. First, there is a need to conduct research regarding the impacts of climate change on agriculture in the region from a multidisciplinary perspective, in order to identify the impact of implementing adaptation and mitigation actions on agricultural productivity patterns. Second, this research highlights the 
importance of identifying crop varieties that are better adapted to the new climatic conditions in the region. The adoption of this measure should be accompanied by dissemination campaigns to share experiences from other farmers and offer information on the economic, social, and environmental benefits of adopting these practices. Third, training schemes on agricultural practices of adaptation and mitigation should be generated by agricultural associations to improve the rational use and conservation of natural resources, in order to reduce the risk aversion and increase the likeliness of implementing the new practices. Finally, economic incentive programs should be established that could help farmers to introduce new sustainable management practices at the farm level that increase their productivity and respect the environment, specifically mitigation actions.

In this study, one of the limitations was related to the data collection process in terms of the veracity of the economic information gathered from farmers. Some producers were not able to provide all the needed information and others refrained from responding reliably to the questions, due to either a lack of understanding or lack of interest. For further research, it could be interesting to include variables accounting for social and environmental externalities in the calculation of efficiency to better highlight a more sustainable indicator.

Supplementary Materials: The following are available online at http://www.mdpi.com/2071-1050/11/12/3291/s1.

Author Contributions: M.A.O.T. conceived and designed the study, investigated, performed data collection, and wrote the manuscript; Z.K. conceived and designed the research, reviewed and edited, participated in writing the manuscript and was the supervisor of all procedures; S.I.O.H. made the formal analysis of the data and participated in writing the manuscript; B.G. participated in analysis of the data.

Funding: This research received no external funding.

Acknowledgments: The National Council of Science and Technology (CONACYT) and UPC's Centre for Development Cooperation (CCD-UPC) are thanked for the support to carry out this research.

Conflicts of Interest: The authors declare no conflicts of interest.

\section{References}

1. Smit, B.; Pilifosova, O. Adaptation to climate change in the context of sustainable development and equity. Sustain. Dev. 2003, 8, 9.

2. Lampis, A.; Pabón-Caicedo, J.D. Presentación del dossier Cambio climático: Territorios e instituciones. Cuad. Geogr.-Rev. Colomb. Geogr. 2018, 27, 225-226.

3. Tao, S.; Xu, Y.; Liu, K.; Pan, J.; Gou, S. Research progress in agricultural vulnerability to climate change. Adv. Clim. Chang. Res. 2011, 2. [CrossRef]

4. Zamora, M. Cambio climático. Rev. Mex. Cienc. For. 2015, 6, 4-7.

5. Gornall, J.; Betts, R.; Burke, E.; Clark, R.; Camp, J.; Willett, K.; Wiltshire, A. Implications of climate change for agricultural productivity in the early twenty-first century. Philos. Trans. R. Soc. B Biol. Sci. 2010, 365, 2973-2989. [CrossRef] [PubMed]

6. Vargas, A.R. Cambio Climático, Agua y Agricultura; Desde la Dirección de Liderazgo Técnico y Gestión del Conocimiento-IICA: San José, Costa Rica, 2007; p. 13.

7. Pomareda, C. Políticas Públicas para la Adaptación a la Variabilidad del Clima y al Cambio Climático; Políticas y Sistemas de Incentivos para el Fomento y Adopción de Buenas Prácticas Agrícolas; CATIE: Turrialba, Costa Rica, 2009; p. 147.

8. Campos, M.; Velazquez, A.; McCall, M. Adaptation strategies to climatic variability: A case study of small-scale farmers in rural Mexico. Land Use Policy 2014, 38, 533-540. [CrossRef]

9. IPCC. Climate Change 2014: Mitigation of Climate Change; Contribution of Working Group III to the Fifth Assessment Report of the Intergovernmental Panel on Climate Change; Edenhofer, O., Pichs-Madruga, R., Sokona, Y., Farahani, E., Kadner, S., Seyboth, K., Adler, A., Baum, I., Brunner, S., Eickemeier, P., et al., Eds.; Cambridge University Press: Cambridge, UK; New York, NY, USA, 2014.

10. Alston, J.; Pardey, P. Agriculture in the global economy. J. Econ. Perspect. 2014, 28, 121-146. [CrossRef]

11. World Bank. Employment in Agriculture (\% of Total Employment) (Modeled ILO Estimate). 2019. Available online: https://data.worldbank.org/indicator/sl.agr.empl.zs (accessed on 24 May 2019). 
12. Orduño, M.; Kallas, Z.; Ornelas, S. Analysis of Farmers' Stated Risk Using Lotteries and Their Perceptions of Climate Change in the Northwest of Mexico. Agronomy 2019, 9, 4. [CrossRef]

13. Khanal, U.; Wilson, C.; Lee, B.; Hoang, V.-N. Do climate change adaptation practices improve technical efficiency of smallholder farmers? Evidence from Nepal. Clim. Chang. 2018, 147, 507-521. [CrossRef]

14. Saiyut, P.; Bunyasiri, I.; Sirisupluxana, P.; Mahathanaseth, I. The impact of age structure on technical efficiency in Thai agriculture. Kasetsart J. Soc. Sci. 2017, 1-7. [CrossRef]

15. Ullah, R.; Shivakoti, G.P.; Ali, G. Factors Effecting Farmers' Risk Attitude and Risk Perceptions: The Case of Khyber Pakhtunkhwa, Pakistan. Int. J. Disaster Risk Reduct. 2015, 13, 151-157. [CrossRef]

16. Mase, A.S.; Gramig, B.M.; Prokopy, L.S. Climate change beliefs, risk perceptions, and adaptation behavior among Midwestern US crop farmers. Clim. Risk Manag. 2017, 15, 8-17. [CrossRef]

17. Castaño, N.; Cardona, M. Determining factors in Colombian agricultural sector instability. En Contexto 2014, 2, 1-258.

18. Ghaffar, A. Climate change and associated spatial heterogeneity of Pakistan: Empirical evidence using multidisciplinary approach. Sci. Total Environ. 2018, 634, 95-108.

19. Bellow, T.; Mutabazi, K.; Kirschke, D.; Franke, Ch.; Siëer, S.; Siebert, R.; Tscherning, K. Can farmers' adaptation to climate change be explained by socio-economic household-level variables? Glob. Environ. Chang. 2012, 22, 223-235. [CrossRef]

20. Martínez-Castillo, R. Sistemas de producción agrícola sostenible. Rev. Tecnol. Marcha 2009, $22,23$.

21. Bizimana, J.C.; Richardson, J. Agricultural technology assessment for smallholder farms: An analysis using a farm simulation model (FARMSIM). Comput. Electron. Agric. 2019, 156, 406-425. [CrossRef]

22. Bidegain, M.; Crisci, C.; Del Puerto, L.; Inda, H.; Mazzeo, N.; Taks, J.; Terra, R. Clima de Cambios: Nuevos Desafíos de Adaptación en Uruguay. Project FAO-MGAP. TCP URU/3302. 2012. Available online: http://www.fao.org/climatechange/80141/es/ (accessed on 24 April 2018).

23. Cecena, M.I.; Vega, D.C. Agricultural chemicals and its impact on the quality of water resources: The case of the Valley of Carrizo, Sinaloa, Mexico. AQUA Mundi 2011, 157-162. [CrossRef]

24. CONAGUA Comisión Nacional del Agua; Secretaría de Medio Ambiente y Recursos Naturales. Estadísticas Agrícolas de los Distritos de Riego Año Agrícola 2015-2016; Edición: Mexico City, Mexico, 2017.

25. Lara, P.E.; Valdez, V.J.; Medina, T.S.; Martinez, R.R. Situación de la agricultura de Mayos y Mestizos del norte del Sinaloa, Mexico. Agric. Soc. Desarro 2017, 14, 577-597.

26. López, A.; Hernández, D. Cambio climático y agricultura: Una revisión de la literatura con énfasis en América Latina. Trimest. Econ. 2016, 83, 459-496. [CrossRef]

27. Rojas, R. Guía para Realizar Investigaciones Sociales, 40th ed.; Plaza y Valdez S.A.: Mexico City, Mexico, 2005.

28. Kallas, Z.; Serra, T.; Gil, J. Farmers' objectives as determinants of organic farming adoption: The case of Catalonian vineyard production. Agric. Econ. 2010, 41, 409-423. [CrossRef]

29. Aigner, D.; Lovell, C.K.; Schmidt, P. Formulation and estimation of stochastic frontier production function models. J. Econom. 1977, 6, 21-37. [CrossRef]

30. Meeusen, W.; van den Broeck, J. Technical efficiency and dimension of the firm: Some results on the use of frontier production functions. Empir. Econ. 1977, 2, 109-122. [CrossRef]

31. Guesmi, B.; Serra, T.; Kallas, Z.; Gil Roig, J.M. The productive efficiency of organic farming: The case of grape sector in Catalonia. Span. J. Agric. Res. 2012, 3, 552-566. [CrossRef]

32. Saaty, T.L. Toma de Decisiones para Líderes; RWS Publications: Pittsburg, CA, USA, 1997.

33. Saaty, T.L. Fundamentals of the analytic hierarchy process. In The Analytic Hierarchy Process in Natural Resource and Environmental Decision Making; Springer: Dordrecht, The Netherlands, 2001.

34. Mendoza, A.; Ospino, W.A.; y Romero, D.S. Aplicación de los métodos de toma de decisiones LP-GW-AHP y lógica difusa para la selección de una electiva académica en la Universidad del Atlántico, Colombia. Rev. Virtual Univ. Catól. Norte 2016, 48, 351-364.

35. Lee, D.; Edmeades, S.; De Nys, E.; McDonald, A.; Janssen, W. Developing local adaptation strategies for climate change in agriculture: A priority-setting approach with application to Latin America. Glob. Environ. Chang. 2014, 29, 78-91. [CrossRef]

36. Olesen, J.; Bindi, M. Consequences of climate change for European agricultural productivity, land use and policy. Eur. J. Agron. 2002, 16, 239-262. [CrossRef]

37. Castells, D.; Lopez, M.; McDermott, T. Adaptation to climate change: A review through a development economics lens. World Dev. 2018, 104, 183-196. [CrossRef] 
38. Xiaohong, Z.; Jia, H.; Junxin, C. Study on Mitigation Strategies of Methane Emission from Rice Paddies in the Implementation of Ecological Agriculture. Energy Proced. 2011, 5, 2474-2480. [CrossRef]

39. Moniruzzaman, S. Crop choice as climate change adaptation: Evidence from Bangladesh. Ecol. Econ. 2015, 118, 90-98. [CrossRef]

40. Mangalassery, S.; Mooney, S.; Sparkes, D.; Fraser, W.; Sjogersten, S. Impacts of zero tillage on soil enzyme activities, microbial characteristics and organic matter functional chemistry in temperate soils. Eur. J. Soil Biol. 2015, 68, 9-17. [CrossRef]

41. Mohamed, H.; Krauss, S.; Samsuddin, S. A systematic review on Asian's farmers' adaptation practices towardsclimate change. Sci. Total Environ. 2018, 644, 683-695.

42. Liu, X.; Zhang, S.; Bae, J. The impact of renewable energy and agriculture on carbon dioxide emissions: Investigating the environmental Kuznets curve in four. J. Clean. Prod. 2017, 164, 1239-1247. [CrossRef]

43. Waha, K.; Muller, C.; Bondeau, A.; Dietrich, J.; Kurukulasuriya, P.; Heinke, J.; Lotze-Campen, H. Adaptation to climate change through the choice of cropping system and sowing date in sub-Saharan Africa. Glob. Environ. Chang. 2013, 23, 130-143. [CrossRef]

44. Yue, Q.; Xu, X.; Hillier, J.; Cheng, K.; Pan, G. Mitigating greenhouse gas emissions in agriculture: From farm production to food consumption. J. Clean. Prod. 2017, 149, 1011-1019. [CrossRef]

45. Siraj, S.; Mikhailov, L.; Keane, J. Decision Support Contribution of individual judgments toward inconsistency in pairwise comparisons. Eur. J. Oper. Res. 2015, 242, 557-567. [CrossRef]

46. Holt, C.A.; Laury, S.K. Risk Aversion and Incentive Effects. Am. Econ. Rev. 2002, 92, 1644-1655. [CrossRef]

47. Saaty, T.L.; y Vargas, L.G. Comparison of eigenvalue, logarithmic least squares and least squares methods in estimating ratios. Math. Model. 1984, 5, 309-324. [CrossRef]

48. Saaty, T.L. The Analytic Hierarchy Process; McGraw-Hill: New York, NY, USA, 1980.

49. Reyna, C.; Bressán, E.; Mola, D.; Belaus, A. Validating the Structure of the New Ecological Paradigm Scale among Argentine Citizens through Different Approaches. Pensam. Psicol. 2018, 16, 107-118. [CrossRef]

50. Gomera, A.; Villamandos, F.; Vaquero, M. Construction of indicators of environmental beliefs from the NEP scale. Acc. Psicol. 2013, 10, 147-160.

51. Moreno, M.; Corraliza, J.A.; Ruiz, J.P. Escala de actitudes ambientales hacia problemas específicos. Psicothema 2005, 17, 502-508.

52. Sharma, S.; Aragón Correa, J.A.; Rueda, A. Gestión medioambiental proactiva: Validación de un instrumento de medida. In Comunicación Presentada en el XIII Congreso Nacional de ACEDE; Publisher: Salamanca, Spain, 2003.

53. Dunlap, R.; Liere, K.V.; Mertig, A.; Jones, R.E. Measuring Endorsement of the New Ecological Paradigm: A Revised NEP Scale. J. Soc. Issues 2000, 56, 425-442. [CrossRef]

54. Hawcroft, L.; Milfont, T.L. The use (and abuse) of the new environmental paradigm scale over the last 30 years: A meta-analysis. J. Environ. Psychol. 2010, 30, 143-158. [CrossRef]

55. Vozmediano, L.; San Juan, C. Escala Nuevo Paradigma Ecológico: Propiedades psicométricas con una muestra española obtenida a través de Internet. Medio Ambient. Comport. Hum. 2005, 6, 37-49.

56. Mejìa, J. Tolerancia y Aversión al Riesgo. 2015. Available online: https://www.21tradingcoach.com/ es/formaci\%C3\%B3n-gratuita/an\%C3\%A1lisis-cuantitativo/128-tolerancia-y-aversi\%C3\%B3n-al-riesgo (accessed on 8 February 2019).

57. Brick, K.; Visser, M.; Burns, J. Risk Aversion: Experimental Evidence from South African Fishing Communities. Am. J. Agric. Econ. 2012, 94, 133-152. [CrossRef]

58. IDAE. Instituto para la Diversificación y Ahorro de la Energía. Ahorro, Eficiencia Energética y Sistemas de Laboreo Agrícola; IDEA: Madrid, Spain, 2006.

59. Alam, G.M.; Alam, K.; Mushtaq, S. Climate change perceptions and local adaptation strategies of hazard-prone rural households in Bangladesh. Clim. Risk Manag. 2017, 17, 52-63. [CrossRef]

60. Niles, M.T.; Mueller, N.D. Farmer perceptions of climate change: Associations with observed temperature and precipitation trends, irrigation, and climate beliefs. Glob. Environ. Chang. 2016, 39, 133-142. [CrossRef]

61. Intergovernmental Panel on Climate Change (IPCC). Climate Change; IPCC: Geneva, Switzerland, 2014.

62. Gori, A.; Brito, B.; Ruiz, J. Climate Change and Agriculture: Do Environmental Preservation and Ecosystem Services Matter? Ecol. Econ. 2018, 152, 27-39.

63. Greenpeace. La Agricultura Mexicana y el Cambio; Greenpeace: Mexico City, Mexico, 2010; Volume 1, pp. 4-11. 
64. Morales-Casco, L.A.; Zúniga-González, C. A Impactos del cambio climático en la agricultura y seguridad alimentaria. Rev. Iberoam. Bioecon. Cambio Clim. 2016, 2, 269.

65. Fadhelab, S.; Rico, M.A.; Hana, D. Sensitivity of peak flow to the change of rainfall temporal pattern due to warmer climate. J. Hydrol. 2018, 560, 546-559. [CrossRef]

66. Araus, J.; Slafer, G.; Royo, C.; Serret, M. Breeding for yield potential and stress adaptation in cereals. Crit. Rev. Plant Sci. 2008, 27, 377-412. [CrossRef]

67. Stocker, T.F.; Qin, D.; Plattner, G.-K.; Tignor, M.M.B.; Allen, S.K.; Boschung, J.; Nauels, A.; Xia, Y.; Bex, V.; Midgley, P.M. Cambio Climático. Bases Físicas. 2013. Available online: https://www.ipcc.ch/pdf/assessmentreport/ar5/wg1/WG1AR5_SummaryVolume_FINAL_SPANISH.pdf (accessed on 21 September 2018).

68. Quiroga, A. Impactos del Cambio Climático en la Incidencia de Plagas y Enfermedades de los Cultivos. 2013. Available online: https://www.croplifela.org/es/actualidad/articulos/197-impactos-del-cambio-climatico-enla-incidencia-de-plagas-y-enfermedades-de-los-cultivos (accessed on 12 September 2017).

69. Vásquez, L. Cambio Climático, Incidencia de Plagas y Prácticas Agroecológicas Resilientes; Instituto Nacional de Ciencias Agrícolas (INCA): La Habana, Cuba, 2011.

70. Galindo, L.M. La Economía del Cambio Climático en Mexico. Semarnat 2013, 53, 1689-1699.

71. Márquez, T.; Velásquez, A.; Flores, J.; Flores, S.; y Garzón, H. Determinantes de la eficiencia técnica de explotaciones de frijol ubicadas en Portuguesa, Venezuela. Temas Agrar. 2013, 18, 67-82. [CrossRef]

72. Karunarathna, M.; Wilson, C. Agricultural biodiversity and farm level technical efficiency: An empirical investigation. J. For. Econ. 2017, 29, 38-46. [CrossRef]

73. Ovares, R.G. El cambio climático en la agenda política: Un problema mundial. Rev. Ing. 2016, 26, 59-70.

74. Perdomo, J.; y Hueth, D. Funciones de Producción y Eficiencia Técnica en el eje Cafetero Colombiano: Una Aproximación con Frontera Estocástica; Universidad de los Andes: Bogotá, Colombia, 2010.

75. Bragado, M.A. El Régimen Internacional del Cambio Climático y los Retos para México; El Colegio de San Luis A.C.: San Luis Potosí, Mexico, 2016.

76. Naess, A. Self-Realization: An Ecological Approach to Being in the World. In Deep Ecology for the 21st Century; Sessions, G., Ed.; Shambhala: Boston, MA, USA; Londres, UK, 1995; pp. 224-239.

77. Pennings, J.M.E.; Garcia, P. Measuring producers' risk preferences: A global risk-attitude construct. Am. J. Agric. Econ. 2001, 83, 993-1009. [CrossRef]

78. Perdomo, J.A.; y Mendieta, J.C. Factores que afectan la eficiencia técnica y asignativa en el sector cafetero colombiano: Una aplicación con análisis envolvente de datos. Rev. Desarro. Soc. 2007. [CrossRef]

79. Sánchez, B.I.; Kallas, Z.; Rojas, O.; Gil, J.M. Determinant Factors of the Adoption of Improved Maize Seeds in Southern Mexico: A Survival Analysis Approach. Sustainability 2018, 10, 3543. [CrossRef]

80. Cardozo, N.; de Oliveira Bordonal, R.; La Scala, N., Jr. Sustainable intensification of sugarcane production under irrigation systems, considering climate interactions and agricultural efficiency. J. Clean. Prod. 2018, 204, 861-871. [CrossRef]

81. Alvarez, A.; Del Corral, J. Identifying different technologies using a latent class model: Extensive versus intensive dairy farms. Eur. Rev. Agric. Econ. 2010, 37, 231-250. [CrossRef]

82. Parks, M.M.; Brekken, C.A. Cosmovisions and Farming Praxis: An Investigation of Conventional and Alternative Farmers along the Willamette River. Cult. Agric. Food Environ. 2018. [CrossRef]

83. Ortiz, R. El Cambio Climático y la Producción Agrícola; Banco Interamericano de desarrollo: Washington, DC, USA, 2012; pp. 13-17.

(C) 2019 by the authors. Licensee MDPI, Basel, Switzerland. This article is an open access article distributed under the terms and conditions of the Creative Commons Attribution (CC BY) license (http://creativecommons.org/licenses/by/4.0/). 